\title{
Consumers' willingness to pay (WTP) premium price for organic fruits and vegetables (OFV) in Western Tamil Nadu
}

\author{
P. BALAJI
}

Received : 24.12.2015; Revised : 15.02.2016; Accepted : 16.03.2016

\begin{abstract}
Organic food market of India is estimated of 1,000 crore which is growing 20-22 per cent, with about 95 per cent of the brands existing in top 10 metros and other tier II cities (Business Standard, 2012). There are variety of factors that can potentially influence consumers towards OFV consumption like concern for health, environmental protection and chemical residues in conventional food products, pesticides, nutritional concern, as well as improved taste and flavour in organic food products (Ngui et al., 2011). It is also important to understand how willing people are to pay premium price for organic products. The objective of the study is to identify the factors influence the consumer's Willingness to pay (WTP) premium price for Organic fruits and vegetables in Coimbatore city. Primary data were collected with the aid of pretested interview schedule from the selected 400 sample consumer by adopting "mall intercept survey method" (Phau and Teah, 2009). Percentage analysis and ordered logit model were used to analyze the data. The major share of the sample respondents were young, middle aged males, mostly educated and employed, with the annual income ranging from Rs. 2 lakhs to Rs. 5 lakhs. Income, awareness, knowledge and education had significantly influenced the consumers' willingness to pay more for organic fruits and vegetables.
\end{abstract}

KEY WORDS : Consumers, Willingness to pay, Fruits, Vegetables, Ordered logit model

How to cite this paper : Balaji, P. (2016). Consumers' willingness to pay (WTP) premium price for organic fruits and vegetables (OFV) in Western Tamil Nadu. Internat. J. Com. \& Bus. Manage, 9 (1) : 36-39. 